\title{
UJI KADAR FLUORIDA DALAM AIR MINUM KEMASAN TAHUN 2015
}

Fadella Vilutama, Ferry Kriswandana, Darjati

\begin{abstract}
Studies in the Harvard School of Public Health (HSPH) and the China Medical University of Shenyang in 2012 showed that fluorides beyond the standard levels defined in the United States $(0.7$ to $1.2 \mathrm{mg} / \mathrm{L})$ are capable of affecting IQ of children. Therefore, fluoride levels in drinking water in Indonesia need to be controlled. The purpose of the present study was to determine the levels of fluoride in drinking water in accordance with the SNI 01-3553-2006 regarding Bottled Drinking Water.

The present study was a descriptives research. Samples were taken at Supermarket $C$ and examined at the Center for Health Laboratory Surabaya. Data were tabulated and descriptively analyzed.

Result showed that the samples examined did not qualify the SNI 01-3553-2006 regarding Bottled Drinking Water. The excessive levels of fluoride may cause public health problems. One of these health problems is dental fluorosis, a decrease in IQ of children and an increase in the risk of fractures.

The levels of fluoride in bottled drinking water in the study ranged from the smallest $0.907 \mathrm{mg} / \mathrm{L}$ to the largest $1.498 \mathrm{mg} / \mathrm{L}$. The future researchers are recommended to study the effectiveness of bio-carbon filters from the plant Tridax procumbens to eliminate the levels of fluoride in drinking water with temperature variations.
\end{abstract}

Keyword : Fluoride, bottled drinking water

\section{PENDAHULUAN}

Air adalah kebutuhan utama untuk kelangsungan hidup manusia dan jumlahnya harus mencukupi, aman serta dapat dijangkau untuk semua orang. Air merupakan sumber kehidupan bagi manusia. Oleh karena itu, air juga memiliki peran dalam mengganggu kesehatan manusia jika tidak aman dikonsumsi.

Air minum adalah air yang melalui proses pengolahan atau tanpa proses pengolahan yang memenuhi syarat kesehatan dan dapat langsung diminum. (Kepmenkes No 492 Tahun 2010). Air minum yang memenuhi syarat kesehatan merupakan air minum yang memenuhi syarat fisik, kimia, biologi dan radioaktifitas.

Meningkatkan mutu air khususnya air minum akan memberikan manfaat yang nyata bagi kesehatan. Maka dari itu, perlu adanya upaya untuk dapat mencapai mutu air minum yang aman. Dewasa ini, masyarakat telah banyak yang mengkonsumsi air minum kemasan dibandingkan air minum olahan sendiri. Pengolahan air secara konvensional sudah mulai ditinggalkan. Produsen-produsen air minum mulai menjamur di berbagai wilayah. Banyak merk dagang bermunculan di pasaran yang berisi air minum.

Menurut Standar Nasional Indonesia 01-3553-2006 tentang Air Minum dalam Kemasan, air minum dalam kemasan adalah air baku yang telah diproses, dikemas dan aman diminum mencangkup air mineral dan air demineral.

Air minum kemasan yang telah banyak dipasarkan sekarang memiliki posisi yang sangat strategis. Jumlah konsumen yang banyak dan juga air minum kemasan yang langsung diminum sehingga memudahkan pajanan secara langsung pada tubuh masyarakat.

Masalah kesehatan yang terkait dengan aspek kimiawi pada air minum akan muncul akibat kemampuan kontituen kimiawi untuk menyebabkan efek kesehatan dalam periode pajanan yang panjang. Banyak zat kimia yang terdapat dalam air minum namun hanya beberapa yang dapat menimbulkan efek langsung yang buruk untuk kesehatan dalam setiap keadaan tertentu. Pajanan oleh zat kimia, salah satunya Fluorida yang berkadar tinggi, meskipun terjadi secara alamiah dapat menyebabkan karies gigi dan pada kasus yang parah dapat menyebabkan fluorosis pada tulang.

Pada penelitian sebelumnya yang dilakukan oleh Harvard School of Public Health (HSPH) dan China Medical University di Shenyang menunjukkan hasil bahwa Fluorida yang melebihi kadar maksimal dalam air minum dapat mempengaruhi perkembangan kognitif pada anak-anak.

Dari penelitian di atas, dapat disimpulkan bahwa Fluorida boleh ada dalam air minum jika kadarnya tidak melebihi standar yang telah ditentukan. Fluorida tidak hanya ada dalam air minum tetapi juga ada 
dalam makanan, produk gigi dan juga udara. Sehingga jika dalam air minum terdapat Fluorida dengan kadar yang tinggi, maka kelebihan asupan Fluorida ini dapat menimbulkan masalah pada kesehatan manusia.

\section{TUJUAN}

Mengetahui kadar Fluorida dalam air minum kemasan jenis botol volume $600 \mathrm{ml}$ sesuai dengan SNI 01-3553-2006 tentang Air Minum Dalam Kemasan

\section{METODE PENELITIAN \\ Jenis Penelitian}

Penelitian ini termasuk jenis penelitian deskriptif

\section{Obyek Penelitian}

Obyek penelitian ini adalah air minum dalam kemasan (air mineral) dengan jenis kemasan adalah botol volume $600 \mathrm{ml}$

\section{Pengumpulan Data}

Pengumpulan data dilakukan dengan cara mengukur kadar Fluorida yang terkandung dalam air minum kemasan

\section{Analisis Data}

Analisa dilakukan secara deskriptif untuk menganalisis ketelitian dari hasil pengukuran kadar Fluorida dalam air minum kemasan.

\section{HASIL PENELITIAN DAN PEMBAHASAN}

Pemeriksaan air sampel dilakukan di Balai Besar Laboratorium Kesehatan Surabaya dengan parameter Fluorida. Sebelum dilakukan pengambilan sampel, peneliti melakukan survei ke 10 minimarket dan swalayan tentang merek apa saja yang paling banyak dibeli oleh pelanggan. Dan dari hasil survei tersebut, didapatkan daftar 10 merek air minum kemasan botol volume $600 \mathrm{ml}$.

Keadaan fisik sampel saat di lokasi pengambilan sampel dan di laboratorium sama, yaitu jernih, kemasan tidak cacat, masih tersegel, dan tidak ada benda asing (misal: kotoran fisik berbentuk seperti lumut).

Tiap botol sampel kemudian diberi kode mulai $A 1, A 2, A 3, B 1, B 2, B 3, C 1, C 2$, C3, D1, D2, D3, E1, E2, E3, F1, F2, F3, G1, G2, G3, H1, H2, H3, I1, I2, I3, J1, J2, J3.

Dari hasil pemeriksaan kadar Fluorida dalam air minum kemasan botol $600 \mathrm{ml}$ menunjukkan bahwa semua air minum dalam kemasan yang diteliti melebihi batas maksimum yang diperbolehkan oleh SNI 013553-2006 tentang Air Minum Dalam Kemasan sehingga kesepuluh merek air minum dalam kemasan tidak memenuhi syarat yang berlaku.

Jumlah sampel yang diteliti sebanyak 10 merek air minum dalam kemasan yang masing-masing dilakukan pengulangan sebanyak 3 kali. Range data hasil pemeriksaan kadar Fluorida mulai dari yang terkecil sebesar 0,907 $\mathrm{mg} / \mathrm{L}$ pada sampel $\mathrm{C} 1$ dan yang terbesar sebesar $1,498 \mathrm{mg} / \mathrm{L}$ pada sampel I2.

Berdasarkan analisis deskriptif dari hasil pemeriksaan kadar Fluorida menunjukkan bahwa data sangat bervariasi.

Sesuai dengan hasil penelitian yang menunjukkan seluruh sampel tidak memenuhi syarat SNI 01-3553-2006 tentang Air Minum Dalam Kemasan. Kadar Fluorida yang berlebih dalam sampel dapat berpengaruh terhadap kesehatan untuk yang mengkonsumsinya. Terlalu banyak terpapar Fluorida dapat mengakibatkan Dental Fluorosis dan keracunan akut.

Menurut Allen Buresz dalam artikelnya yang berjudul "Scientific Facts on the Biological Effects of Fluorides" menjelaskan bahwa paparan Fluorida yang berlebihan dapat menyebabkan berbagai macam efek, salah satunya adalah mengganggu sintesis kolagen dan menyebabkan kerusakan kolagen pada tulang, tendon, otot, kulit, tulang rawan, paru-paru, ginjal dan trakea (AK Susheela dan Mohan Jha, Perpustakaan Compendium, 1981),

Menurut EPA, Fluorida memiliki manfaat yang kurang untuk kesehatan gigi dan bahaya untuk kesehatan manusia. Bahaya ini termasuk dalam bahaya toksik akut, seperti gangguan pada fungsi ginjal, bahaya beracun, kanker, efek pada reproduksi, neurotoksisitas, patologi tulang dan fluorosis gigi.

Di dalam sebuah buku berjudul "Fluoride The Aging Factor" yang ditulis oleh John Yiamouyiannis menyebutkan bahwa Dental Fluorosis merupakan tanda pertama karena kontaminan Fluorida. Selanjutnya jika terus terkontaminai maka akan terjadi kerusakan gigi pada stadium lanjut dan gigi tanggal. Pada penelitian di China juga menyebutkan bahwa, pemberian Fluorida dengan dosis rendah pun telah menyebabkan berkurangnya kecerdasan pada anak-anak.

Menurut The National Research Council(NRC), Fluorida yang berlebih dalam tulang dapat meningkatkan resiko patah tulang karena menurunkan maa tulang. Konsumsi Fluorida melalui air minum berFluorida terbukti meningkatkan kemungkinan patah tulang.

Begitu banyak dampak merugikan yang disebabkan Fluorida dalam air minum. Oleh karena itu, pengolahan air minum merupakan upaya untuk mendapatkan air yang bisa dikonsumsi dan sehat sesuai dengan standar mutu air untuk kesehatan. Dengan adanya perlakuan awal sebelum air 
dikonsumsi setidaknya bisa mengurangi dampak negatif terhadap kesehatan masyarakat dari kontaminasi Fluorida.

Salah satu caranya adalah dengan Tanaman Tridax procumbens. Tanaman ini digunakan oleh The International Journal of Environmental Engineering sebagai fliter Bio Carbon untuk menghilangkan Fluorida dalam air minum.

Tanaman Tridax procumbens ini berasal dari Amerika bagian tropis, atau nama lainnya adalah Gletang (sebutan tanaman Tridax procumbens dalam bahasa indonesia) bisa ditemukan di tempat-tempat kering dan disinari matahari yang cerah. Tanaman ini biasanya digunakan oleh penduduk Amerika sebagai penutup atap rumah dan pakan ternak pada zaman tersebut.

Menurut Kimiawan Malairajan Singanan dari The Presidency College, di Chennai, yang telah menyelidiki Tridax procumbens, yang biasanya digunakan sebagai ramuan obat di India, dapat juga digunakan sebagai penyerap Bio Carbon untuk Fluorida. Dalam penelitian tersebut dijelaskan bahwa dengan mencampurkan jaringan tanaman Tridax procumbens dengan ion aluminium memungkinkan untuk membuat filter Bio Carbon yang aman untuk menyerap ion Fluorida dari air yang dihangatkan pada suhu sekitar $27^{\circ} \mathrm{C}$ dengan melewati filter. "percobaannya menunjukkan bahwa dibutuhkan hanya tiga jam untuk menghilangkan 98 \% Fluorida dengan hanya 2 gram filter Bio Carbon."

\section{KESIMPULAN}

Dari 30 sampel air minum dalam kemasan jenis botol volume $600 \mathrm{ml}$ yang diperiksa diperoleh hasil kandungan Fluorida dari yang terkecil sebesar $0,907 \mathrm{mg} / \mathrm{L}$ pada sampel $\mathrm{C} 1$ dan terbesar $1,498 \mathrm{mg} / \mathrm{L}$ pada merek I2.

Kadar Fluorida yang terkandung dalam 10 merek Air Minum Kemasan tidak memenuhi syarat SNI 01-3553-2006 tentang Air Minum Dalam Kemasan sehingga hal ini perlu diwaspadai karena dapat menimbulkan masalah kesehatan pada manusia seperti Dental Fluorosis, menurunkan tingkat IQ pada anak-anak dan meningkatkan resiko patah tulang.

\section{SARAN}

Pemerintah atau pihak yang berwenang hendaknya mewaspadai adanya indikasi kandungan Fluorida dalam Air Minum Kemasan. Hal ini mengingat jumlah konsumen Air Minum Dalam Kemasan semakin meningkat.

Kepada peneliti selanjutnya disarankan untuk melakukan penelitian mengenai efektifitas filter Bio Carbon dari tanaman Tridax procumbens untuk menghilangkan kadar Fluorida dalam air minum dengan variasi suhu.

\section{DAFTAR PUSTAKA}

Amrih, Pitoyo. 2005.

Cara Memastikan Air yang Anda Minum Bukan Sumber Penyakit. Ebook www.pitoyo.com. Solo. Diakses pada tanggal 22 Desember 2014 pukul 21.08 WIB

Ariens, J. E., dkk. 1986. Pengantar Toksikologi Umum. Gajah Mada University Press, Yogyakarta: 12. .

BSN. 2006. SNI 01-3553-2006 Air Minum Dalam Kemasan. Jakarta: 1 2.

BSN. 2006. SNI 01-3554-2006

Cara Uji Air Minum Dalam Kemasan. Jakarta: $16-17$.

Chandra, Budiman. 2007. Pengantar Kesehatan Lingkungan. Jakarta, EGC: 40.

HSPH. 2012. Impact of Fluoride on Neurological Development in Children. http://www.hsph.harvard. edu/news/. Diakses pada tanggal 22 Desember 2014 pukul 20.53 WIB

Keputusan Menteri Perindustrian dan Perdagangan Republik Indonesia Nomor 705 Tahun 2003 Tentang Persyaratan Teknis Industri Air Minum Dalam Kemasan dan Perdagangannya.

Kusnoputranto, H. 1986. Kesehatan Lingkungan. Fakultas Kesehatan Masyarakat Universitas Indonesia. Jakarta: 22-23.

L., Choi, Anna, et all. 2012. Development Fluoride Neurotoxicity: A Systematic Review and Meta-Analysis. Environmental Health Perspectives. Volume 120: 1362 - 1368. Diakses pada tanggal 17 Desember 2014 pukul 12.23 WIB

Notoatmodjo, Soekidjo. 2005. Metodologi Penelitian Kesehatan. Jakarta, Rineka Cipta.

Peraturan Menteri Kesehatan Republik Indonesia Nomor 492 Tahun 2010 Tentang Persyaratan Kualitas Air Minum.

Peraturan Menteri Kesehatan Republik Indonesia Nomor 01 Tahun 1975 Tentang Standar Kualitas Air Minum.

Soetijo, Pitoyo dan Purwantoyo, Eling. 2002. Deteksi Pencemar Air Minum. Demak, CV Aneka Ilmu: 70. 
USU Institutional Repository. 2011. Pengolahan Air. Universitas Sumatera Utara: $12-14$.

WHO. 2004. Guidelines for Drinking Water Quality. Geneva, WHO Library Catalouging. Third Edition. Widyastuti, Palupi dan Apriningsih (penerjemah). 2011. Pedoman Mutu Air Minum. Jakarta, EGC, Edisi Ketiga: $555-558$.

WHO. 2006. Fluoride in Dringking Water. London, IWA Publishing : 5 13. 